\title{
Biochemical characterization, microbial diversity and biodegradability of coastal sediments in the Gulf of Gabès, Southern Mediterranean Sea
}

\author{
M. Jeddi ${ }^{1} \cdot$ F. Karray ${ }^{1} \cdot$ A. Battimelli ${ }^{2} \cdot$ A. Danel $^{2} \cdot$ S. Melliti Ben Garali ${ }^{3} \cdot$ M. Tedetti ${ }^{4} \cdot$ H. Zaghden ${ }^{1} \cdot$ N. Mhiri ${ }^{1}$. \\ P. Sousbie ${ }^{2} \cdot$ D. Patureau ${ }^{2} \cdot$ S. Sayadi ${ }^{5}$
}

\begin{abstract}
Coastal sediments are considered to be final receptacles for organic and inorganic contaminants. Characterizing those sedi-ments and assessing their biodegradation potential have become a great challenge in recent years. In this study, the chemical composition, including the content in polycyclic aromatic hydrocarbons, the microbial community abundance and diversity (using culture-independent approaches targeting 16S rRNA genes), and the aerobic/anaerobic biodegradation potential of coastal sediments collected in the Sfax coastal area (Gulf of Gabès, Southern Mediterranean Sea) were investigated. The highest concentration of total polycyclic aromatic hydrocarbons $\left(981 \mu \mathrm{g} \mathrm{kg}^{-1} \mathrm{dw}\right)$ was recorded in Sidi Mansour harbor sediment, emphasized pyrogenic and petrogenic hydrocarbon sources. Organic matter, including total organic carbon, and the ultimate aerobic biodegradability, with $30 \%$ as the highest value in Sidi Salem channel sediment, were in a positive accordance with bacterial communities assigned within Actinobacteria, Clostridia and Flavobacteria classes. The correlation noticed between Thermocladium and Thermogladius genera and sulfate content explained that Sidi Mansour and PK4 sedi-ments are located in terrestrial acid-sulfate areas. The highest cumulative methane produced with Marseille inoculum and Tunisian inoculum was recorded in Sidi Salem sediment and strongly correlated with methanogens among Methanobacteria, Methanococci and Methanomicobia classes showing the presence of industrial and municipal sources. The bioavailability of low and moderate polycyclic aromatic hydrocarbons in the current study may explain the occurrence of Methanobacterium which positively correlated with the anaerobic biodegradability using Tunisian inoculum with 50\% as the highest value in Sidi Mansour sediment.
\end{abstract}

Keywords Aerobic/anaerobic biodegradation potential $\cdot$ Methanogens $\cdot$ Microbial community $\cdot$ Polycyclic aromatic hydrocarbons $\cdot$ Sfax coastal area

M. Jeddirmariemjeddi12@gmail.com

1 Laboratory of Environmental Bioprocesses, Centre of Biotechnology of Sfax, B.P 1177, 3018 Sfax, Tunisia

2 LBE, INRA, Univ Montpellier, Narbonne, France

3 Laboratoire de Phytoplanctonologie, Faculté Des Sciences de Bizerte, Université de Carthage, Bizerte, Tunisia

4 CNRS, IRD, Aix Marseille Univ, Université de Toulon, MIO UM 110, 13288 Marseille, France

5 Center for Sustainable Development, College of Arts and Sciences, Qatar University, 2713 Doha, Qatar

\section{Introduction}

Coastal sediments are known to be receptacles of organic and inorganic contaminants entering the coastal marine environment through sedimentation of particles. At the same time, coastal sediments may be sources of contaminants for the water column during sedimentary resuspension events and subsequent remobilization of contaminants (Dang et al. 2015; Guigue et al. 2017). This potential release of contaminants from sediments to the water column may involve an impact on marine biota and the adaptation of microbial communities (Dang et al. 2014, 2015; Zouch et al. 2018). It has been shown that the diversity and functioning of prokaryotic communities in coastal marine sediments could be affected by their content in contaminants (Abell et al. 2014; Tangherlini et al. 2020). The diversity of carbon 
sources for prokaryotic communities could be increased due to the presence of more or less biodegradable organic contaminants, leading to new ecological niches (Acosta-Gonzalez and Marques 2016; Misson et al. 2016). The development of high-throughput sequencing technologies allows us to expand the knowledge about chemical contamination impacts on microbial diversity and potential consequences on ecosystem functioning (Aylagas et al. 2017). However, only a few works have been conducted until now to assess this link between the chemical composition/contamination level and the prokaryotic diversity and abundance in coastal sediments. Misson et al. (2016) showed a strong correlation between bacterial richness and both anthropogenic and natural chemical composition, although weaker relationships were observed between archaeal richness and chemical variables.

In turn, prokaryotes can modify the fate of contaminants in coastal marine sediments by influencing their mobility (toxic metals) and degradation processes (organic contaminants). Indeed, anaerobic biodegradation experiments have been performed to assess the conversion of recalcitrant compounds, such as polycyclic aromatic hydrocarbons (PAHs), pesticides, chlorinated solvents and polychlorinated biphenyls (Vidali 2001). Increasing attention has been given recently to the application of biotechnological strategies based on the biostimulation of microbial communities to accelerate the biodegradation/bioconversion processes of organic and inorganic contaminants in coastal sediments. These strategies include the characterization of microbial communities' structure and the identification of populations associated, with a greater understanding of how physicochemical factors may affect the biodegradation potential of contaminants. Such investigations were used to clarify the possibilities and limits of anaerobic bioremediation strategies and also to reinforce the knowledge of microbial processes in coastal sediments.

The Gulf of Gabès (Tunisia, Southern Mediterranean Sea) is considered to be a very productive and of great diversity region within the Mediterranean and is the main fishing area of Tunisia (Bel Hassen et al. 2009; D'Ortenzio and D'Alcalà, 2009; El Zrelli et al. 2017; Rabaoui et al. 2014). Nevertheless, the Gulf of Gabès is also strongly affected by anthropogenic inputs, caused by the important population development and the growth of industrial and agricultural activities. The coastal area of Sfax city, located in the northern part of the Gulf of Gabès, is impacted by intensive human activities, fishing and commercial harbors, municipal landfills, chemical and industrial effluents, oil and gas field exploitations, as well as agriculture and aquaculture activities (Aloulou et al. 2012; Fourati et al. 2018). Anthropogenic activities present harmful threats to the marine ecosystems (Yonglong et al. 2016). For this reason, knowing the levels of contaminants and biodegradation potential of these coastal sediments has become a major issue, especially in the Gulf of Gabès, which remains a poorly explored marine area from this point of view.

In this context, the objectives of this study were first to investigate the chemical composition and the diversity and abundance of prokaryotic communities (Bacteria and Archaea) in three contrasted surface sediments collected along the Sfax coastal zone. The diversity and abundance of prokaryotic communities were determined using cultureindependent approaches targeting 16S rRNA genes (Illumina Miseq sequencing and quantitative polymerase chain reaction (Q-PCR), with $m c r A$ genes encoding methyl coenzyme $M$ reductase used to determine methanogens abundance; secondly, to assess the aerobic/anaerobic biodegradability of sedimentary organic matter and contaminants; and finally, to determine the potential link between the chemical composition and the microbial community structure of those sediments.

\section{Materials and Methods}

\section{Sampling sites and procedures}

The three surface sediment samples were collected on January 27, 2016, in the Sfax coastal area, located in the northern part of the Gulf of Gabès (Tunisia, Southern Mediterranean Sea). These sediments have been chosen because they are impacted by different anthropogenic inputs. One sample was collected at the outlet of the rainwater drain channel ("PK4"), which crosses the Sfax city from the southwest to the northeast. PK4 is thus impacted by runoffs and urban discharges. One sample was taken in the Sidi Mansour fishing harbor ("PP") in the northern part of Sfax city. This site is subjected to petroleum inputs. The latter sample was collected in the Sidi Salem channel ("SS"), situated in the southern part of Sfax city. Sidi Salem releases various industrial wastes into the sea, including those of the Sfax slaughter house, agricultural alimentary industries and soap factories, as well as wastewater treatment plant (WWTP) effluent.

The surface sediment samples $(0-5 \mathrm{~cm})$ were collected using a clean spatula, in the morning in low tide and clear sky conditions. Samples were transferred into previously washed polypropylene bottles that were stored in the dark in the cold and then immediately frozen at $-20^{\circ} \mathrm{C}$ until analysis and experiments. 


\section{Biological and physicochemical analysis}

\section{Biochemical methane potential (BMP) analysis}

BMP was determined according to Raposo et al. (2011). For this purpose, wet sediments and two types of fresh and preincubated inocula were used. One inoculum originated from upflow anaerobic sludge blanket (UASB) digester in sugar industry in Marseille, France (MI), and an inoculum from anaerobic sludge treatment station in Tunis, Tunisia (TI).

\section{Physicochemical analysis}

Content in cations and anions, $\mathrm{pH}$ and electrical conductivity (EC) were measured with a liquid-solid (LS) ratio of $10 \mathrm{~mL}$ extractant (deionized water)/g dry lyophilized sediment. The extraction was conducted during $48 \mathrm{~h}$ followed by a centrifugation to separate the solid and liquid phases. Then, a filtration through $0.45-\mu$ m polypropylene filtration membrane was operated. Leachate subsamples were collected and stored as appropriate for ionic chromatography analysis (ICS 3000, Dionex, USA) as described elsewhere (Kosson et al. 2002).

\section{Biological analysis}

Total solids (TS) and volatile solids (VS) were determined in wet samples using standard methods (APHA 1985). Chemical oxygen demand (COD) and biochemical oxygen demand (BOD) protocols were applied to wet sediments. Total Kjeldahl nitrogen (TKN) was determined in lyophilized sediments as described by Akhiar et al. (2016). Total carbon (TC) and total inorganic carbon (TIC) were measured in lyophilized sediments as described in Battimelli et al. (2010). For total organic carbon (TOC) determination, lyophilized sediments were acidified with $1 \mathrm{~N} \mathrm{HCl}$ in order to remove inorganic carbon. Hydrogen $(\mathrm{H})$ and sulfur $(\mathrm{S})$ elements were determined on lyophilized and homogenized sediments (fraction $<200 \mu \mathrm{m}$ ) by an SC-144 LECO elemental analyzer at combustion temperatures of $1050{ }^{\circ} \mathrm{C}(\mathrm{H})$ or $1350{ }^{\circ} \mathrm{C}(\mathrm{S})$ in oxygen atmosphere (Zaghden et al. 2017). C, H and S were expressed in \% of dried weight ( $\% \mathrm{dw})$.

\section{Granulometric analysis}

The laser particle size analysis (granulometry) was done after 2-mm sieving and treatment with $\mathrm{H}_{2} \mathrm{O}_{2}$ and $\mathrm{HCl}$ using a granulometric laser. The results are expressed in $\%$ of sand $(2000-63 \mu \mathrm{m})$, silt $(63-2 \mu \mathrm{m})$ and clay $(<2 \mu \mathrm{m})$ of sediment samples.

\section{PAH analysis}

For the determination of PAH concentrations, duplicate frozen sediment samples were dried using a ventilated oven ( $60 \mathrm{~h}$ at $40{ }^{\circ} \mathrm{C}$ ), crushed and sieved on a 2-mm mesh size and stored at $20^{\circ} \mathrm{C}$ in the dark until extraction. An Accelerated Solvent Extraction ASE-200 system (Dionex) was used to perform the extraction from dried samples. Hexane and acetone mixture (50:50 v:v) was the extraction solvent used for the experiment. The ASE cells were filled from bottom to the top, a filter of glass fiber (19-mm diameter, Whatmann), $1 \mathrm{~g}$ of alumina (Sigma), 1 or $0.5 \mathrm{~g}$ of dried sediment and $1.5 \mathrm{~g}$ of Hydromatrix (Varian). For extraction procedure, cells were heated at $120^{\circ} \mathrm{C}$ and with a pressure of 100 bars for 2 cycles and a static time of extraction of $5 \mathrm{~min}$. The extract was evaporated under nitrogen flow to dryness. The dry extract was then dissolved in $2 \mathrm{~mL}$ of acetonitrile and was immediately analyzed using high-performance liquid chromatography (HPLC). The gradient of elution of the 13 PAHs was performed from acetonitrile/water (60/40\%, v/v) to acetonitrile $(100 \%)$. The upper and lower limits of the calibration curves were between $5-750 \mu \mathrm{g} \mathrm{L}^{-1}$ for a quantification limit (LOQ) of $3 \mu \mathrm{g} \mathrm{L}^{-1}$ (Trably et al. 2004).

\section{Quality assurance and quality control of PAHs}

During the PAH experiments, wearing nitrile gloves and mask was necessary in order to avoid contaminations and contact with skin. Glassware including glass brown preservative vials were previously cleaned with acetone or heated. Cells were cleaned with acetone in the ultrasonic water bath. Eight standards were used for PAH calibration with concentrations varying between $5,10,25,50,100,250,500$ and $750 \mu \mathrm{g} \mathrm{L}^{-1}$ obtained by diluting a concentrated stock solution of $10 \mathrm{mg} \mathrm{L}^{-1}$ (PAH MIX 9, CIL Cluzeau). Each ten samples (extracts in acetonitrile), a standard of 50, 100 or $250 \mu \mathrm{g} \mathrm{L}^{-1}$ was injected in order to verify the instrument stability. Each extract was run two times. A recalibration was done with respect to the obtained standard deviation of the control samples.

\section{DNA extraction, Illumina sequencing and data processing}

The three coastal sediments were firstly centrifuged at $10.000 \mathrm{~g}$ for $5 \mathrm{~min}$; the pellets were stored at $-20^{\circ} \mathrm{C}$ once the supernatant removed. The EZ-10 Spin Column Soil DNA Mini-preps Kit was used to extract DNA from pellets of the mixed sludge samples; it was performed according to the manufacturer's protocol. The NanoDrop ND-2000 Spectrophotometer (Thermo Scientific) was used to determine the concentration and the quality of rDNA gene. 
Sequencing of PCR amplicons of 16S rDNA was conducted with the Illumina MiSeq platform (CBS, Sfax, Tunisia) targeting the V3-V4 hyper variable regions of coastal sediments using universal prokaryotic primers (Pro341/ Pro805R) and archaeal specific primers sets (ARC344F/ Arch806R) (Takahashi et al. 2014) for $1 \times 300$-bp single end sequencing (Illumina). PCR amplification was performed in triplicate in $25 \mu \mathrm{L}$ reactions with $12.5 \mu \mathrm{L}$ of $2 \times$ KAPA HIFI Hot Start Ready Mix (KAPA Biosystems), $0.2 \mu \mathrm{M}$ of forward and reverse primers and about $5 \mathrm{ng} \mu \mathrm{L}^{-1}$ DNA. Thermal cycling consisted of initial denaturation at $95{ }^{\circ} \mathrm{C}$ for $3 \mathrm{~min}$, followed by 30 cycles of denaturation at $95{ }^{\circ} \mathrm{C}$ for $30 \mathrm{~s}$, annealing at $55^{\circ} \mathrm{C}$ for $30 \mathrm{~s}$, and elongation at $72{ }^{\circ} \mathrm{C}$ for $30 \mathrm{~s}$, and finally $72{ }^{\circ} \mathrm{C}$ for $5 \mathrm{~min}$. The PCR products were analyzed on $2 \%$ agarose gel. Illumina library preparations of the amplified and cleaned PCR products were performed. The library quality was assessed on the Qubit®3.0 Fluorometer (Thermo Scientific) and Agilent Bioanalyzer 2100 system. QIIME software package 1.9 was used to analyze raw data obtained from the Illumina MiSeq sequencing platform. Sequences were filtered for low-quality sequences and checked for chimera by UCHIME. The high-quality sequences were then clustered into operational taxonomic units (OTUs) using a 97\% identity threshold with UCLUST (Edgar 2010). QIIME software package was used to analyze alpha diversity (Chao1, observed OTU Species, Simpson and Shannon index and PD whole tree) (Caporaso et al. 2010). Representative sequences selected from dominant OTUs ( $>1 \%$ of total sequences) were picked out and the taxonomic assignment was obtained by querying NCBI (National Center for Biotechnology Information) nucleotide. The online sequence analysis resources "BLAST" (Basic Local Alignment Search Tool) was used to define sequence similarity searches (Altschul et al. 1997).

\section{Nucleotide sequence accession number}

Resulting nucleotides sequences deposited in Gen Bank database have the following accession numbers: MK092340-MK092367 for bacteria and MK097279-MK097318 for archaea.

\section{Real-Time PCR quantification}

Real-time PCR (RT-PCR) assays targeting archaeal and bacterial 16S RNA gene were performed using C1000 ${ }^{\mathrm{TM}}$ Thermo Cycleur CFX96-Real-Time System (Bio-Rad). The primer sets $344 \mathrm{~F} / 519 \mathrm{R}$ and $331 \mathrm{~F} / 797 \mathrm{R}$ were used to quantify copy numbers of bacterial and archaeal $16 \mathrm{~S}$ rRNA genes, respectively. The Q-PCR mixture of a total volume of $10 \mu \mathrm{L}$ consisted on Sso Advanced SYBR Green Supermix kit (Bio-Rad) including $0.25 \mu \mathrm{L}$ of each primer (final concentration, $500 \mathrm{nM}$ each), $5 \mu \mathrm{L}$ of Sso Advanced universal SYBR Green supermix (final concentration, 1x) and $1 \mu \mathrm{L}$ of template DNA. Negative controls without template DNA were included with each Q-PCR conducted. The bacterial RT-PCRs consisted on an initial denaturing step of $10 \mathrm{~min}$ at $95{ }^{\circ} \mathrm{C}$, followed by 35 cycles of $30 \mathrm{~s}$ of denaturing at $95{ }^{\circ} \mathrm{C}, 30 \mathrm{~s}$ of annealing phase at $60{ }^{\circ} \mathrm{C}$ and $30 \mathrm{~s}$ of primer extension at $72{ }^{\circ} \mathrm{C}$. The archaeal RT-PCRs were started by an initial denaturation at $98{ }^{\circ} \mathrm{C}$ for 2 min and 39 cycles of a two-step PCR protocol with a $5 \mathrm{~s}$ denaturation phase at $98{ }^{\circ} \mathrm{C}$ and followed by an annealing/elongation phase for $30 \mathrm{~s}$ at $56{ }^{\circ} \mathrm{C}$ (Jeddi et al. 2020). The amplification of standard DNA fragments was performed from Halomonas alimentaria $Y K J-16^{T}$ for bacterial $16 \mathrm{~S}$ rRNA gene Q-PCR and from Halorubrum chaoviator DSM 19316 for archaeal 16S rRNA gene Q-PCR (Jeddi et al. 2020). McrA functional gene of the group-specific methanogens was amplified by proceeding to an initial denaturation for $10 \mathrm{~min}$ at $95{ }^{\circ} \mathrm{C}$ followed by 40 cycles of $5 \mathrm{~s}$ at $95{ }^{\circ} \mathrm{C}, 30 \mathrm{~s}$ at annealing temperature of $55^{\circ} \mathrm{C}$ and an extension for $30 \mathrm{~s}$ at $72{ }^{\circ} \mathrm{C}$. Primer pairs McrAF-McrAR targeting methanogens were used to amplify standard DNA fragments from Methanosarcina acetivorans. Template DNA prepared from samples was analyzed in duplicate. Primers used in this research for RT-PCR of each domain and their characteristics are found in supplementary material (S1). Standard curves were generated and their quality parameters were judged with the slope and the correlation coefficient $\left(\mathrm{R}^{2}\right)$ which was higher than $99 \%$.

\section{Statistical analyses}

Spearman's rank correlation coefficient (also called Spearman's rho) is a nonparametric measure for evaluating the degree of linear correlation between two independent variables (Gauthier 2001). Spearman's correlation test was performed using SPSS 18.0 software. For these different analyses and tests conducted, the significance threshold was set at $p<0.05$. For a size $\mathrm{n}$ of 3 data samples (SS, PK4 and PP), the Spearman correlation was used to assess the relationships between various biochemical variables (TOC, $\mathrm{SO}_{4}{ }^{2-}, \mathrm{PAH}, \mathrm{BOD}_{42} / \mathrm{COD}$, cumulative $\mathrm{CH}_{4}$-TI, cumulative $\mathrm{CH}_{4}$-MI, BMP-TI and anaerobic biodegradability-TI) and microbial community variables (Bacteria and Archaea). 
Table 1 Total 13 PAH, physicochemical parameters, cations and anions, biochemical analysis, particle size distribution and microbial abundance of coastal sediments

\begin{tabular}{|c|c|c|c|}
\hline Coastal sediment parameters & Sidi Salem channel & PK4 outfall & Sidi Mansour harbor \\
\hline Total $13 P A H\left(\mu g \mathrm{~kg}^{-1} \mathrm{dw}\right)$ & $435 \pm 5.6$ & $224 \pm 1.9$ & $981 \pm 4.5$ \\
\hline Fluorene & $19 \pm 0.2$ & $8 \pm 0.3$ & $16 \pm 0.1$ \\
\hline Phenanthrene & $102 \pm 0.9$ & $35 \pm 0.2$ & $181 \pm 2.3$ \\
\hline Anthracene & $8 \pm 0.2$ & $3 \pm 0.1$ & $194 \pm 1.4$ \\
\hline Fluoranthene & $27 \pm 0.5$ & $13 \pm 0.7$ & $55 \pm 0.4$ \\
\hline Pyrene & $103 \pm 0.7$ & $108 \pm 2.4$ & $139 \pm 0.6$ \\
\hline Benzo(a)anthracene & - & - & $65 \pm 0.34$ \\
\hline Chrysene & $75 \pm 1.2$ & $15 \pm 0.5$ & $83 \pm 0.6$ \\
\hline Benzo(b)fluoranthene & $27 \pm 0.5$ & $13 \pm 0.7$ & $55 \pm 0.4$ \\
\hline Benzo(k)fluoranthene & - & - & $25 \pm 0.5$ \\
\hline Benzo(a)pyrene & $15 \pm 0.4$ & - & $60 \pm 0.3$ \\
\hline DiBenzo(a,h)anthracene & $6 \pm 0.4$ & $3 \pm 0.2$ & $14 \pm 0.3$ \\
\hline Benzo(g.h.i)perylene & $39 \pm 4.1$ & $20 \pm 1.5$ & $58 \pm 0.9$ \\
\hline Indeno(123 cd)pyrene & $15 \pm 0.2$ & $7 \pm 0.3$ & $37 \pm 0.3$ \\
\hline \multicolumn{4}{|l|}{ Physicochemical parameters } \\
\hline $\mathrm{pH}$ & 7.85 & 8.05 & 8.48 \\
\hline Conductivity $\left(\mathrm{mS} \mathrm{cm}^{-1}\right)$ & 6.79 & 3.97 & 3.26 \\
\hline \multicolumn{4}{|l|}{ Cations and Anions $\left(g L^{-1}\right)$} \\
\hline $\mathrm{Na}^{+}$ & 1.10 & 0.62 & 0.54 \\
\hline $\mathrm{K}^{+}$ & 0.08 & 0.06 & 0.03 \\
\hline $\mathrm{NH}_{4}^{+}$ & 0.04 & 0.02 & 0.02 \\
\hline $\mathrm{Cl}^{-}$ & 1.84 & 1.02 & 0.90 \\
\hline $\mathrm{SO}_{4}^{2-}$ & 0.04 & 0.15 & 0.12 \\
\hline \multicolumn{4}{|l|}{ Biochemical analysis } \\
\hline $\mathrm{COD}_{\mathrm{T}}\left(\mathrm{g} \mathrm{O}_{2} / \mathrm{L}\right)$ & 77.00 & 39.00 & 13.2 \\
\hline $\mathrm{BOD}_{5}\left(\mathrm{~g} \mathrm{O}_{2} / \mathrm{L}\right)$ & 7.60 & 4.00 & 1.40 \\
\hline TS (\% ww) & 50.20 & 57.5 & 67.0 \\
\hline VS (\% ww) & 7.80 & 4.90 & 3.20 \\
\hline $\mathrm{TC}(\% \mathrm{dw})$ & 6.71 & 5.72 & 1.54 \\
\hline TIC (\% dw) & 1.37 & 3.61 & 1.19 \\
\hline TOC (\% dw) & 5.34 & 2.11 & 0.35 \\
\hline TKN (\% dw) & 0.55 & 0.25 & 0.13 \\
\hline $\mathrm{S}(\% \mathrm{dw})$ & 1.07 & 0.59 & 0.29 \\
\hline $\mathrm{H}(\% \mathrm{dw})$ & 0.83 & 0.41 & 0.20 \\
\hline \multicolumn{4}{|l|}{ Particle size distribution (\%) } \\
\hline Sand $(2000-63 \mu \mathrm{m})$ & 45.19 & 69.86 & 72.52 \\
\hline Silt $(63-2 \mu \mathrm{m})$ & 51.98 & 28.43 & 26.01 \\
\hline Clay $(<2 \mu \mathrm{m})$ & 2.83 & 1.72 & 1.47 \\
\hline \multicolumn{4}{|l|}{ Microbial abundance (copies/g) } \\
\hline Bacteria & $62 \pm 10 \times 10^{7}$ & $1130 \pm 630 \times 10^{7}$ & $74 \pm 15 \times 10^{7}$ \\
\hline Archaea & $0.8 \pm 0.4 \times 10^{7}$ & $4.2 \pm 2 \times 10^{7}$ & $3.1 \pm 10^{7}$ \\
\hline Methanogens & $12.5 \pm 1.4 \times 10^{3}$ & $600 \pm 10^{3}$ & $45.7 \pm 1.2 \times 10^{3}$ \\
\hline
\end{tabular}

\section{Results and discussion}

\section{Chemical characterization and contribution to coastal sediment contamination}

PP sediment presented the highest TS concentration with a rate of $67.1 \%$ wet weight (Table 1). As shown in Table 1,
TOC content was $0.35 \%$ in PP, $2.1 \%$ in PK4 and $5.3 \%$ in SS samples. These values represented, respectively, 7.3, 25 and $34 \%$ of TS. The high TOC content recorded in SS was associated with a low TIC content (1.4\%). The high organic content in SS sediment may be explained by important terrestrial inputs (Sanchez-Mata et al. 1999). In contrast, the highest TIC level was observed for PK4 sediment. The highest VS 
values were found in SS with an average of $7.8 \%$ wet matter, while the lowest ones were recorded in PP (3.2\%). The TOC contents measured here in the three sediments are close to those already reported in sediments of Sfax harbor and Thyna channel, which ranged from 2.75 to $8 \%$, but lower than those observed previously in Sidi Mansour sediment (Zaghden et al. 2016) and higher than those determined in the sediments of Bizerte Lagoon, Tunisia (0.4-3.9\%) (Barhoumi et al. 2014). The rather high TOC concentrations can be due to the eutrophication of this coastal area caused by multiple nutrient inputs (Bel Hassen et al. 2009; D’Ortenzio and D'Alcalà, 2009).

$\mathrm{pH}$ values ranged from 7.85 to 8.48 and for EC, SS site showed a value of $6.79 \mathrm{mS} \mathrm{cm} \mathrm{cm}^{-1}$, whereas for PK4 and PP, values were 3.97 and $3.26 \mathrm{mS} \mathrm{cm}^{-1}$, respectively. The highest EC detected in SS site showed the high water mineralization degree when comparing to the established standard limits (Zaghden et al. 2016), due to $\mathrm{Cl}^{-}\left(1.84 \mathrm{~g} \mathrm{~L}^{-1}\right)$ and $\mathrm{Na}^{+}$ (1.10 $\mathrm{g} \mathrm{L}^{-1}$ ) concentrations (Table 1) which contribute to sediment salinity and electrical conductivity. Furthermore, the important EC in sediments can be explained by the wealth of $\mathrm{Na}^{+}, \mathrm{Ca}^{2+}, \mathrm{Mg}^{2+}$ and $\mathrm{K}^{+}$minerals. TKN detected in the studied sediments showed values between $0.09 \% \mathrm{dw}$ in PP, $0.25 \% \mathrm{dw}$ in PK4 and $0.55 \% \mathrm{dw}$ in SS site (Table 1). This latter value was higher than that reported for harbor sediments in a Mediterranean French site (i.e., $0.3 \% \mathrm{dw}$ of TKN) (Padox et al. 2010). Hence, we may consider that SS site is more influenced by anthropogenic inputs, including domestic and industrial wastes, than the two other sites.

The organic matter origin and sources in the studied sediments can be highlighted by $\mathrm{C} / \mathrm{N}$ ratio. The highest $\mathrm{TOC} /$ TKN ratio in SS site (9.7), in accordance with the highest conductivity in SS sediment, suggested organic matter of both marine and continental origin. Fine sediment fractions (silt and clay) dominated in SS sediment accounting, respectively, for 52.0 and $2.8 \%$ of particle distribution. This fine fraction predominance is known to contribute to the accumulation of contaminants in the sediment (Ujevic et al. 2000). On the other side, sand was the predominant sediment fraction in PK4 and PP sites, with, respectively, 69.9 and $72.5 \%$ of particle distribution. This difference of particle size distribution between the southern (SS) and northern sites (PK4, PP) may be related to different hydrodynamic conditions, with in the north, the presence of an intertidal preventing the deposition of the finest fraction (Aloulou et al. 2012). The highest contents of $H$ and $S$ were recorded in SS sediment with, respectively, 0.83 and $1.07 \%$. The $\mathrm{S}$ content in the studied sediments ranged from 0.29 and $1.07 \%$ and was close to that recorded for superficial sediments of the Sfax-Kerkennah channel (Zaghden et al. 2017).

$\mathrm{COD}$ and $\mathrm{BOD}_{5}$ are useful parameters to estimate the rate of total oxidizable matter in sediment affected by urban and industrial wastes. COD values were $77 \times 10^{3} \mathrm{mg} \mathrm{L}^{-1}$ in $\mathrm{SS}, 39 \times 10^{3} \mathrm{mg} \mathrm{L}^{-1}$ in PK4 and $13.2 \times 10^{3} \mathrm{mg} \mathrm{L}^{-1}$ in PP (Table 1), and were higher than those reported previously in the same Sfax coastal area (from 0.5 to $1.9 \times 10^{3} \mathrm{mg} \mathrm{L}^{-1}$ ) (Drira et al. 2016; Zaghden et al. 2016). The BOD $_{5}$ values reached $7.6 \times 10^{3} \mathrm{mg} \mathrm{L}^{-1}$ in SS, $4 \times 10^{3} \mathrm{mg} \mathrm{L}^{-1}$ in PK4 and $1.4 \times 10^{3} \mathrm{mg} \mathrm{L}^{-1}$ in PP (Table 1), far exceeding the average value measured in Sidi Mansour (200 $\left.\mathrm{mg} \mathrm{L}^{-1}\right)$, Sfax harbor (190 $\mathrm{mg} \mathrm{L}^{-1}$ ) and Ouad Maou channel (300 $\mathrm{mg} \mathrm{L}^{-1}$ ) (Zaghden et al. 2016). In conclusion, the fingerprint of anthropogenic inputs was clearly identified and higher for the SS surface sediment (Sfax southern area).

\section{Concentrations in PAHs}

The total ( $\left.\sum 13\right) \mathrm{PAH}$ concentrations determined in the studied sediments varied between 224 and $981 \mu \mathrm{g} \mathrm{kg}^{-1} \mathrm{dw}$. The highest PAH concentrations were found in PP and SS (Table 1). PAHs of low molecular weight (two and threering, LMW-PAHs) accounted for $21-40 \%$ of the total PAHs in the studied sites. PAHs of moderate molecular weight (four-ring, MMW-PAHs) represented 20-54\% of the total PAHs, whereas high molecular weight PAHs (five and six-ring, HMW-PAHs) accounted for 26-41\%. PK4 sediment had the highest contribution of MMW-PAHs (54\%). The highest concentration (194 $\mathrm{gg} \mathrm{kg}^{-1} \mathrm{dw}$ ) was observed for anthracene series in PP site. Benzo(a)anthracene and benzo(k)fluoranthene were only recorded in PP sediment and were associated with petroleum contamination called petrogenic sources (De Luca et al. 2004). For pyrene series, values of 103,108 and $139 \mu \mathrm{g} \mathrm{kg}^{-1} \mathrm{dw}$ were observed for SS, PK4 and PP stations, respectively. Pyrene was the most abundant compound in SS and PK4 sediments.

Phe/Ant (phenanthrene $v s$ anthracene concentrations) and Flt/Pyr (fluoranthene vs pyrene concentrations) isomeric ratios were determined to assess contamination sources. For PP sediment, a Phe/Ant ratio of 0.9 highlighted strong pyrogenic inputs associated with the combustion of petroleum, wood, coal like creosote and coal tar (Baumard et al. 1998). In addition, the studied stations (SS, PK4 and PP) displayed $\sum \mathrm{LMW} / \sum \mathrm{HMW}$ ratio $<1, \mathrm{Flt} / \mathrm{Flt}+\mathrm{Pyr}$ ratio $<0.4$ and Flt/Pyr ratio between 0.1 and 0.4 , which illustrated both petrogenic and pyrogenic sources of PAHs (Li et al. 2006; Yunker et al. 2002). 
Table 2 Comparison of total PAH concentrations (in $\mu \mathrm{g} \mathrm{kg}^{-1}$ sed. $\mathrm{dw}$ ) in surface sediments from different regions of the Tunisian coastline

\begin{tabular}{|c|c|c|c|c|}
\hline Tunisian site & $\begin{array}{l}\text { Number of } \\
\text { analyzed } \\
\text { PAHs }\end{array}$ & $\begin{array}{l}\text { Range }(\mu \mathrm{g} \\
\mathrm{kg}^{-1} \text { sed. dw) }\end{array}$ & Pollution level $^{\mathrm{a}}$ & Reference \\
\hline Coastal zone of Sfax & 13 & 224-981 & Moderate & This study \\
\hline Gulf of Gabès, Sfax harbor & 17 & $175-10,769$ & Moderate to very high & (Zaghden et al. 2017) \\
\hline Gulf of Gabès, Sfax-Kerkennah channel & 17 & $175-245$ & Moderate & (Zaghden et al. 2017) \\
\hline Gulf of Gabès, Sfax coastline and Kerkennah channel & 17 & $113-10,720$ & Moderate to very high & (Zaghden et al. 2007) \\
\hline Gulf of Gabès, Sfax coastline & 16 & $811-5608$ & Moderate to very high & (Zaghden et al. 2014) \\
\hline $\begin{array}{l}\text { Between the coastal zone of Sfax and the Sfax- Kerken- } \\
\text { nah channel }\end{array}$ & 17 & $150,3-2100$ & Moderate to high & (Zaghden et al. 2007) \\
\hline Near the coastal zone of the Kerkennah Island & 17 & $560,8-955,3$ & Moderate & (Zaghden et al. 2007) \\
\hline The coastal zone of the Kerkennah Island & 17 & 406,2 & Moderate & (Zaghden et al. 2007) \\
\hline Gulf of Tunis (Rades, Goulette, Sidi Bou Said harbors) & 22 & $363-7026$ & Moderate to very high & (Mzoughi and Chouba 2011) \\
\hline Jarzouna-Bizerte coastal area & 17 & $916-3146$ & Moderate to high & (Zrafi-nouira et al. 2010) \\
\hline Coasts of Sfax, Luza, Khniss and Sousse & 14 & $160-1990$ & Moderate to high & (Kessabi et al. 2013) \\
\hline Ghar El Melh Lagoon & 17 & $40-655$ & Low to moderate & (Ben Ameur et al. 2010) \\
\hline Bizerte Lagoon & 16 & $2-537$ & Low to moderate & (Louiz et al. 2008) \\
\hline Bizerte Lagoon & 16 & $83-447$ & Low to moderate & (Trabelsi and Driss 2005) \\
\hline Bizerte Lagoon & 14 & $17-394$ & Low to moderate & (Barhoumi et al. 2014) \\
\hline Khniss coast & 17 & $7-15$ & Low & (Zrafi et al. 2013) \\
\hline
\end{tabular}

${ }^{a}$ The pollution levels are those defined by (Baumard et al. 1998): low: 0-100 $\mu \mathrm{g} \mathrm{kg}^{-1}$; moderate: $100-1000 \mu \mathrm{g} \mathrm{kg}^{-1}$; high: $1000-5000 \mu \mathrm{g} \mathrm{kg}{ }^{-1}$; very high: $>5000 \mu \mathrm{g} \mathrm{kg}^{-1}$; bld: below detection limit

When comparing with other marine areas in the Tunisian coastline as shown in Table 2, the PAH concentrations in this study were generally higher than those found in the Sfax-Kerkennah channel (sum of 17 PAHs between 175 and $245 \mu \mathrm{g} \mathrm{kg}^{-1}$ sed. $\mathrm{dw}$ ), but lower than those observed in the Sfax harbor (sum of 17 PAHs of $10,769 \mu \mathrm{g} \mathrm{kg}^{-1}$ sed. dw) (Zaghden et al. 2017), in the Thyna bay (sum of 16 PAHs of $1929 \mu \mathrm{g} \mathrm{kg}^{-1}$ sed. $\mathrm{dw}$ ) and in the viccinity of the industrial area of phosphogypsum discharge (sum of $16 \mathrm{PAHs}$ of $5608 \mu \mathrm{g} \mathrm{kg}^{-1}$ sed. dw) in the Sfax coastline (Zaghden et al. 2014). Moreover, the PAHs concentrations in this work, were higher than those indicated for Khniss coast, Tunisia (sum of 17 PAHs between 7 and $15 \mu \mathrm{g} \mathrm{kg}^{-1}$ sed. $\mathrm{dw}$ ), but rather lower than those determined in the coasts of Sfax, Luza, Khniss and Sousse (sum of 17 PAHs of $160-1990 \mu \mathrm{g} \mathrm{kg}^{-1}$ sed. dw) (Kessabi et al. 2013). Therefore, the PAH concentrations reported here are relatively moderate compared with those observed in other sediments of the Tunisian coast (Baumard et al. 1998).

\section{Contribution of COD, BOD and BMP to organic matter biodegradability}

The conducted BMP experiment explored the influence of using two different anaerobic inoculums on the digestion of coastal sediments. The results presented in Fig. 1a showed the diversity of biodegradation behaviors of the selected coastal sediments. BOD and BMP variables were expressed with reference to COD concentrations in order to compare the aerobic and anaerobic biodegradability of the organic matter contained in the samples. The specific methane volume produced with both inoculums is expressed in $\mathrm{mL} \mathrm{CH}_{4} / \mathrm{g}$ COD added. The aerobic and anaerobic biodegradability rates were expressed in percentages compared to the theoretical methane volume. The results presented 
Fig. 1 a Average methane production curves for sediments inoculated with Marseille and Tunisian inocula. b Average biochemical oxygen demand in coastal sediments
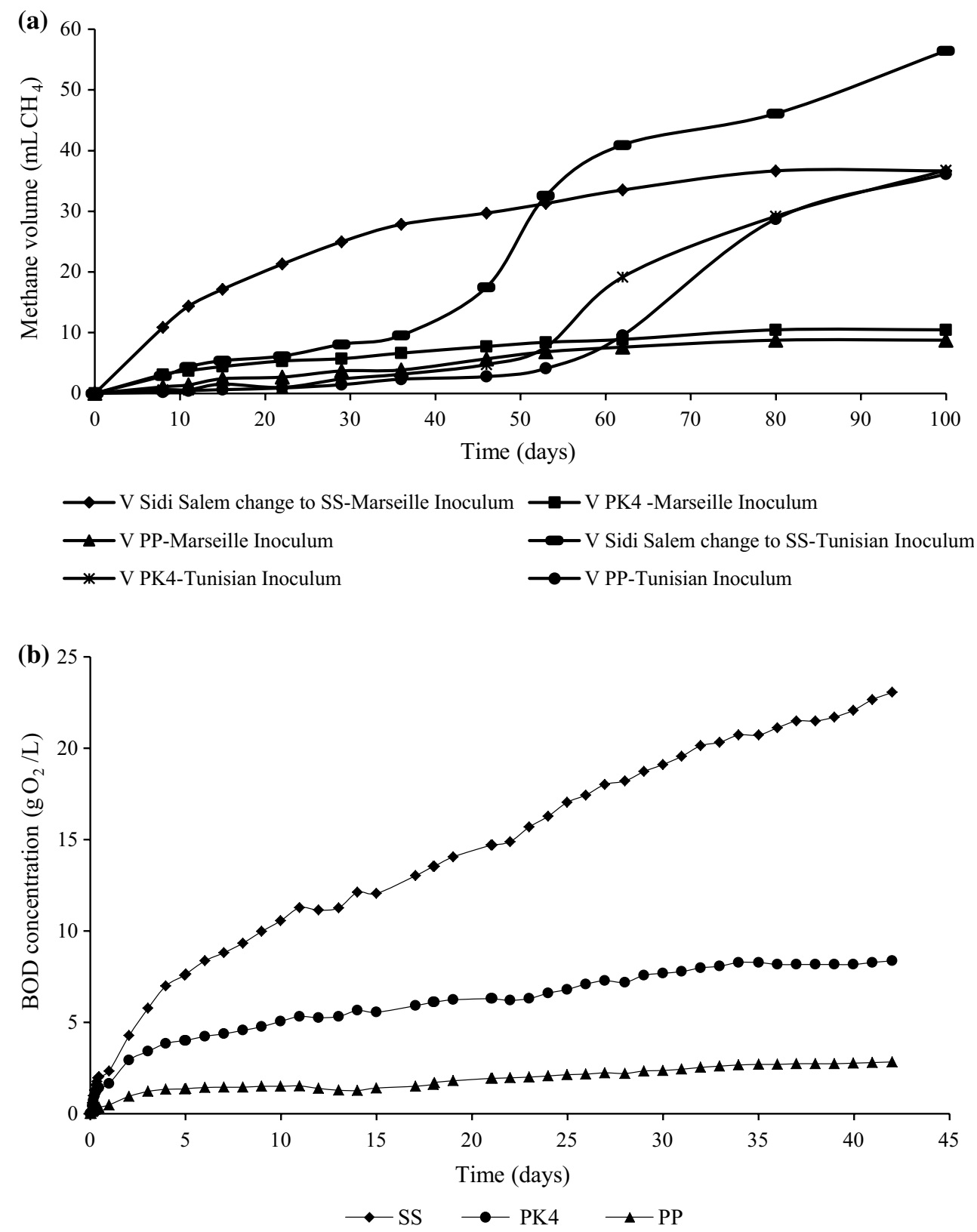

in Table 3 showed that under aerobic conditions, $\mathrm{BOD}_{21} /$ COD ratios varied from 14 to $19 \%$ for the three sites studied reflecting coastal sediments slowly biodegradable in 21 days of incubation (Fig. 1b). Thus, as $\mathrm{BOD}_{5} / \mathrm{COD}$ and $\mathrm{BOD}_{21} /$ COD ratio provides information about the anthropogenic compounds biodegradability and the pollution origin (Yigiterhan et al. 2011; Rhaouat et al. 2014), the $\mathrm{BOD}_{5} / \mathrm{COD}$ ratio lower than $50 \%$ in all sites highlighted a pollution of chemical origin (Rhaouat et al. 2014). Moreover, the $\mathrm{BOD}_{42} /$ COD ratio between 21 and 30\% indicated a slow moderately biodegradability of sediments after 42 days (Fig. 1b). PP sediment with the highest PAH concentration presented $75 \%$ of recalcitrant chemical components compared to other samples (73\% for PK4 and 61\% for SS). So, most of the organic matter in the sediment samples from sites were non-biodegradable with very low content of rapidly 
biodegradable matter with an average of $10 \%$. This may be caused by intense fishing, maritime traffic and industrial effluents generating hardly biodegradable chemical pollution (Zaghden et al. 2014).

Under anaerobic conditions with Marseille inoculum, a biodegradability of 7-21\% was noted with a BMP of $74 \mathrm{~mL} \mathrm{CH}_{4} / \mathrm{g} \mathrm{COD}$ for the most biodegradable SS sediment (Table 3). With Tunisian inoculum, 26-50\% of biodegradability was observed with the highest BMP of $175 \mathrm{~mL} \mathrm{CH}_{4} / \mathrm{g}$ COD (Table 3). The difference in biodegradability was related to a high mineral content in matrices, which was in accordance with the origin of the recalcitrance of organic matter for anaerobic biodegradation. Indeed, the incubation time for Tunisian inoculum was greater than 40 days in order to observe a significant variation in methane production (Fig. 1a). Whereas in the case of Marseille inoculum, a low methanogenic potential was observed for PK4 and PP sediments and a rapid initiation of the methanogenic potential was recorded from the beginning of the incubation for SS sediment, which showed the highest methane production (Fig. 1a).Thus, a sufficient acclimatization period for microflora is required in order to sustain to the changes in the system in the case of a low methanogens metabolism. The overall performance of the ecosystem depended not only on the time of contamination, but also on the degree of contamination allowing the selection of efficient microorganisms (Hayes et al. 1999). Furthermore, the biotransformation of PAHs under anaerobic conditions depended on a sufficiently long adaptation period and appropriate electron acceptors availability (Karthikeyan and Bhandari 2001).

\section{Taxonomic diversity and microbial abundance of bacterial and archaeal communities in coastal sediments}

In order to study the taxonomic diversity of 16S rRNA gene in coastal sediments, prokaryotic universal primers were used for high-throughput sequencing. As shown in Table 4, for prokaryotic communities, OTU numbers ranged between 1052 and 1579 and sequence numbers between 27,258 and 69,122 . The highest richness (observed OTU) and diversity (Simpson and Shannon indexes) were recorded in PK4 sediment. Phylum level derived from different coastal sediments for prokaryotic universal primers are shown in Fig. 2a. In this study, for prokaryotic communities, the abundance of Firmicutes, Proteobacteria, Bacteroidetes and Chloroflexi phyla was noted with different percentages among coastal sediments. Therefore, Firmicutes phylum presented a relative abundance within the studied coastal sediments ranging between 3.6 and $38.6 \%$. SS sequences were mostly assigned to Firmicutes with the highest abundance (38.6\%). The phylum Proteobacteria dominated especially in PK4 sediment with $60.1 \%$ and less in SS (27.6\%) and PP (46.4\%). PK4 sequences were principally assigned to Proteobacteria with 18.5\% for Alphaproteobacteria, 12\% for Betaproteobacteria and $15 \%$ for Deltaproteobacteria. PP sequences were mostly affiliated to Gammaproteobacteria with $25.6 \%$. Furthermore, Bacteroidetes phylum varied between $11.1 \%$ in SS, $13 \%$ in PK4 and $14.8 \%$ in PP and Chloroflexi phylum was noticed at $8.9 \%$ in PP, $4.01 \%$ in PK4 and $2.36 \%$ in SS.

Taxonomic classification at genus level for OTU $>1 \%$ from microbial DNA sequences in the studied coastal sediments compared by blast with NCBI (supplementary
Table 3 Biological analysis, aerobic biodegradability and anaerobic biodegradation potential with Marseille and Tunisian inoculums

\begin{tabular}{|c|c|c|c|}
\hline Coastal sediment analysis & $\begin{array}{l}\text { Sidi Salem } \\
\text { channel }\end{array}$ & PK4 outfall & $\begin{array}{l}\text { Fishing Port } \\
\text { Sidi Man- } \\
\text { sour }\end{array}$ \\
\hline \multicolumn{4}{|l|}{ Biological analysis and aerobic biodegradability } \\
\hline $\mathrm{COD}_{\mathrm{T}}\left(\mathrm{g} \mathrm{O}_{2} / \mathrm{L}\right)$ & 77.0 & 39.0 & 13.2 \\
\hline $\mathrm{BOD}_{5}\left(\mathrm{~g} \mathrm{O}_{2} / \mathrm{L}\right)$ & 7.6 & 4.0 & 1.4 \\
\hline $\mathrm{BOD}_{21}\left(\mathrm{~g} \mathrm{O}_{2} / \mathrm{L}\right)$ & 14.7 & 6.3 & 1.9 \\
\hline $\mathrm{BOD}_{42}\left(\mathrm{~g} \mathrm{O}_{2} / \mathrm{L}\right)$ & 23.1 & 8.4 & 2.8 \\
\hline Rapidly aerobic biodegradability $\mathrm{BOD}_{21} / \mathrm{COD}_{\mathrm{T}}(\%)$ & 19.0 & 16.0 & 14.0 \\
\hline Ultimate aerobic biodegradability $\mathrm{BOD}_{42} / \mathrm{COD}_{\mathrm{T}}(\%)$ & 30 & 21 & 21 \\
\hline \multicolumn{4}{|l|}{ Anaerobic biodegradation potential with MI } \\
\hline Cumulative $\mathrm{CH}_{4}-\mathrm{MI}\left(\mathrm{mL} \mathrm{CH}_{4}\right)$ & 37 & 10 & 9 \\
\hline 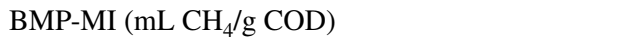 & 74 & 26 & 42 \\
\hline Anaerobic biodegradability-MI (\%) & 21 & 7 & 12 \\
\hline \multicolumn{4}{|l|}{ Anaerobic biodegradation potential with TI } \\
\hline Cumulative $\mathrm{CH}_{4}$-TI $\left(\mathrm{mL} \mathrm{CH}_{4}\right)$ & 56 & 37 & 36 \\
\hline BMP-TI (mL CH $4 / g$ COD) & 114 & 92 & 175 \\
\hline Anaerobic biodegradability-TI (\%) & 33 & 26 & 50 \\
\hline
\end{tabular}


Table 4 Richness and diversity of microbial communities in SS, PK4 and PP samples using prokaryotic universal primers and archaeal specific primers

\begin{tabular}{llrrrrrrr}
\hline Microbes & Sample & Sequence & OTU & OTU > 1\% & Chao & Coverage $(\%)$ & Shannon & Simpson \\
\hline Prokaryotic universal primers & SS & 27,258 & 1052 & 14 & 1126,039 & 93.43 & 8.083 & 0.990 \\
& PK4 & 64,887 & 1579,9 & 9 & 1711,702 & 92.3 & 8.968 & 0.994 \\
& PP & 69,122 & 1476 & 9 & 1553,716 & 95 & 8.950 & 0.994 \\
Archaeal specific primers & SS & 82,744 & 420 & 17 & 424,773 & 98.88 & 5.812 & 0.960 \\
& PK4 & 111,416 & 594 & 18 & 605,053 & 98.18 & 6.006 & 0.952 \\
& PP & 137,834 & 614 & 15 & 618,125 & 99.34 & 6.524 & 0.961 \\
\hline
\end{tabular}

material S2, S3) is illustrated in Fig. 2b. For OTU $>1 \%$, in SS sediment, the presence of a fermentative halophilic anaerobic bacteria called Halanaerobium with $3.17 \%$ was detected, and this genus is affiliated to Firmicutes phylum, order Clostridiales. Clostridiisalibacter genus with $4.9 \%$ and Fusibacter genus with $1.54 \%$ seems to be able to use thiosulfate and elemental sulfur as terminal electron acceptors to produce sulfide (Fadhlaoui et al. 2015). These genera were present in other coastal sediments (PK4 and PP) at very low percentages that did not exceed $1 \%$. Highly abundance of Thioalkalivibrio genus was found in PP sediment with $3.99 \%$, and this genus belongs to Gammaproteobacteria class and is characterized by the ability to remove sulfide from bio and industrial waste gases in full-scale bioreactor (Muyzer et al. 2011). The organic matter degradation in sediments included anaerobic bacterium which are Youngiibacter, related to Firmicutes phylum, and were only present in SS sediment at 3.36\%, and also Clostridium and Acetobacterium genera at 3.17 and $2.38 \%$, respectively. Bifidobacterium genus related to Actinobacteria phylum with a relative abundance of $1.36 \%$ was mostly present in SS sediment. Moreover, marine bacterium of the family Flavobacteriaceae involved Robiginitalea and Actibacter with relative abundance of, respectively, 1.8 and $1.67 \%$ were presented mostly in PP sediment and are involved in anaerobic digestion steps which are hydrolysis and acidogenesis (Dias et al. 2016; Jabari et al. 2016). The aerobic bacterium Cellulophaga genus generally found in marine habitats was present with $2.5 \%$ in SS sediment (Kahng et al. 2009). In addition, bacterial species related to degrading aromatic compounds metabolism were more abundant in PK4 than in SS and PP sites; Thauera aromatica and Thauera phenylacetica contributed to $6.6 \%$ of Thauera genus relative abundance within Betaproteobacteria phylum (Mechichi et al. 2002). Sulfatereducing bacteria present within Deltaproteobacteria phylum included Desulfomicrobium genus, which is isolated from the anoxic contaminated sediments (Duran et al. 2008). Moreover, Desulfotignum genus, with the ability to oxidize the monoaromatic hydrocarbon toluene coupled to hydrogen sulfide production (Ommedal and Torsvik 2007), was mostly present in PK4 at 1.6\%. Desulfosarcina genus, known to oxidize organic compounds or hydrogen and to reduce sulfate into sulfide (Devereux et al. 1989), was noticed at $1.33 \%$ in PP sediment and at $0.64 \%$ in PK4 sediment. Then, other bacterial species contributed to amino acid degradation in bioreactors such as Aminobacterium genus within Synergistaceae family with $1.99 \%$ in PP sediment and very low percentages of $0.37 \%$ in PK4 and $0.2 \%$ in SS sediments (Chertkov et al. 2010). Leptolinea and Thermomarinilinea genera, with relative abundance of 1.27 and $1.07 \%$, respectively, in PP sediment exceeding those in SS and PK4 sediments, were affiliated to the bacterial Chloroflexi taxon and may contribute as well to degradation of carbohydrates (Yamada et al. 2005). Marivita genus related to Alphaproteobacteria phylum with polysaccharide-degrading microorganisms capacities was present in PK4 sediment with 2.25\% (Yoon et al. 2012).

In addition, the relative abundance of archaeal communities using prokaryotic universal primers showed percentages of $3.12 \%$ in SS, $0.97 \%$ in PK4 and $4.16 \%$ in PP sediment from total prokaryotic communities assigned principally to Euryarchaeota phylum and less to Crenarchaeota and Parvarchaeota phyla. With the aim of studying the archaeal communities in the different sites, archaeal specific primers were used. Sequence analysis exhibited that archaeal communities were mostly affiliated to Euryarchaeota phylum with 95, 86.9 and 57.2\%, whereas Crenarchaeota phylum showed 4, 11 and $32.6 \%$ in SS, PK4 and PP sediments, respectively. As well, methanogenic communities recorded using archaeal specific primers represented highly percentages of 82,62 and $29 \%$ from total archaeal communities in SS, PK4 and PP sediments, respectively. Phylum level derived from different coastal sediments for archaea domain is shown in Fig. 2c. As shown in Table 4, for archaeal communities, OTU numbers varied between 420 and 614 and sequence numbers between 82,744 and 137,834 . PP sediment presented the highest sequence and OTU numbers, richness (observed OTU) and diversity (Simpson and Shannon indexes). Taxonomic classification using archaeal specific primers at genus level for OTU $>1 \%$ (Fig. 2d) showed that methanogenic communities included within Euryarchaeota phylum predominate in the studied sediments. 
Fig. 2 a Relative abundance of microbial communities in SS, PK4 and PP samples using Relative phylogenetic abundance was based on frequencies of 16S rRNA gene sequences affiliated with archaeal and bacterial phyla or proteobacterial classes in SS, PK4 and PP samples. b Relative abundance of microbial communities in SS, PK4 and PP samples using prokaryotic universal primers. Relative phylogenetic abunof 16S rRNA gene sequences affiliated with major genera from dominant OTU ( $>1 \%$ of all sequences) in SS, PK4 and PP samples. c Relative abundance of microbial communities in SS, PK4 and PP samples using archaeal specific primers. Relative phylogenetic abundance was based on frequencies of 16S rRNA gene sequences affiliated with archaea and bacterial phyla or proteobactesamples. d Relative abundance of microbial communities in SS, PK4 and PP samples using tive phylogenetic abundance was based on frequencies of 16S rRNAgene sequences affiliated with major genera from dominant OTU ( $>1 \%$ of all samples prokaryotic universal primers. dance was based on frequencies rial classes in SS, PK4 and PP archaeal specific primers. Relasequences) in SS, PK4 and PP
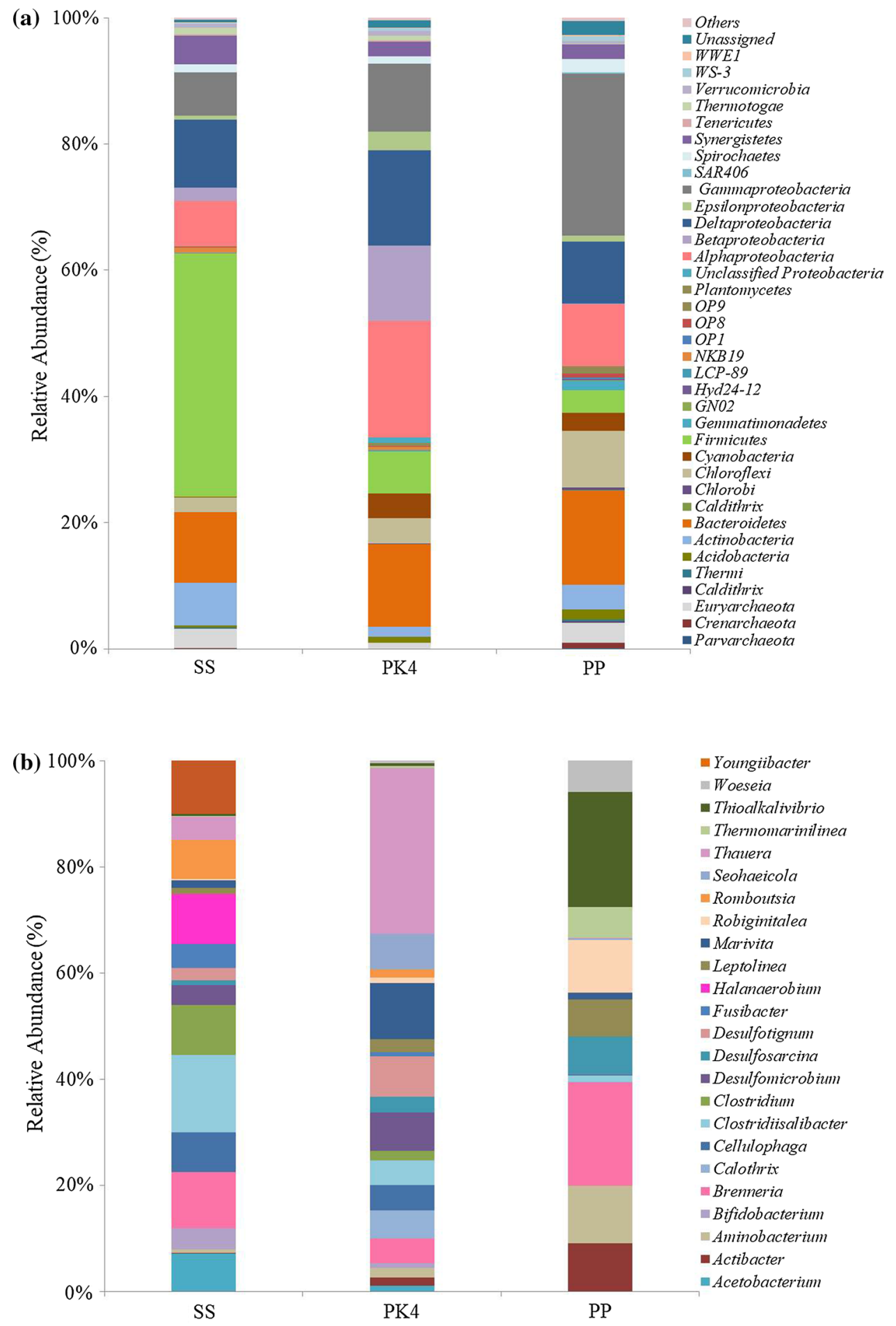

Therefore, Methanobrevibacter genus was the most abundant with 38\% in SS sediment, and this genus grows with $\mathrm{H}_{2}, \mathrm{CO}_{2}$ and formate and probably present in human faeces and originated from a municipal sewage digester (Miller and Lin 2002). In addition, Methanosarcina genus was dominant in SS sediment with the highest percentage of $6.8 \%$. It is 
Fig. 2 (continued)
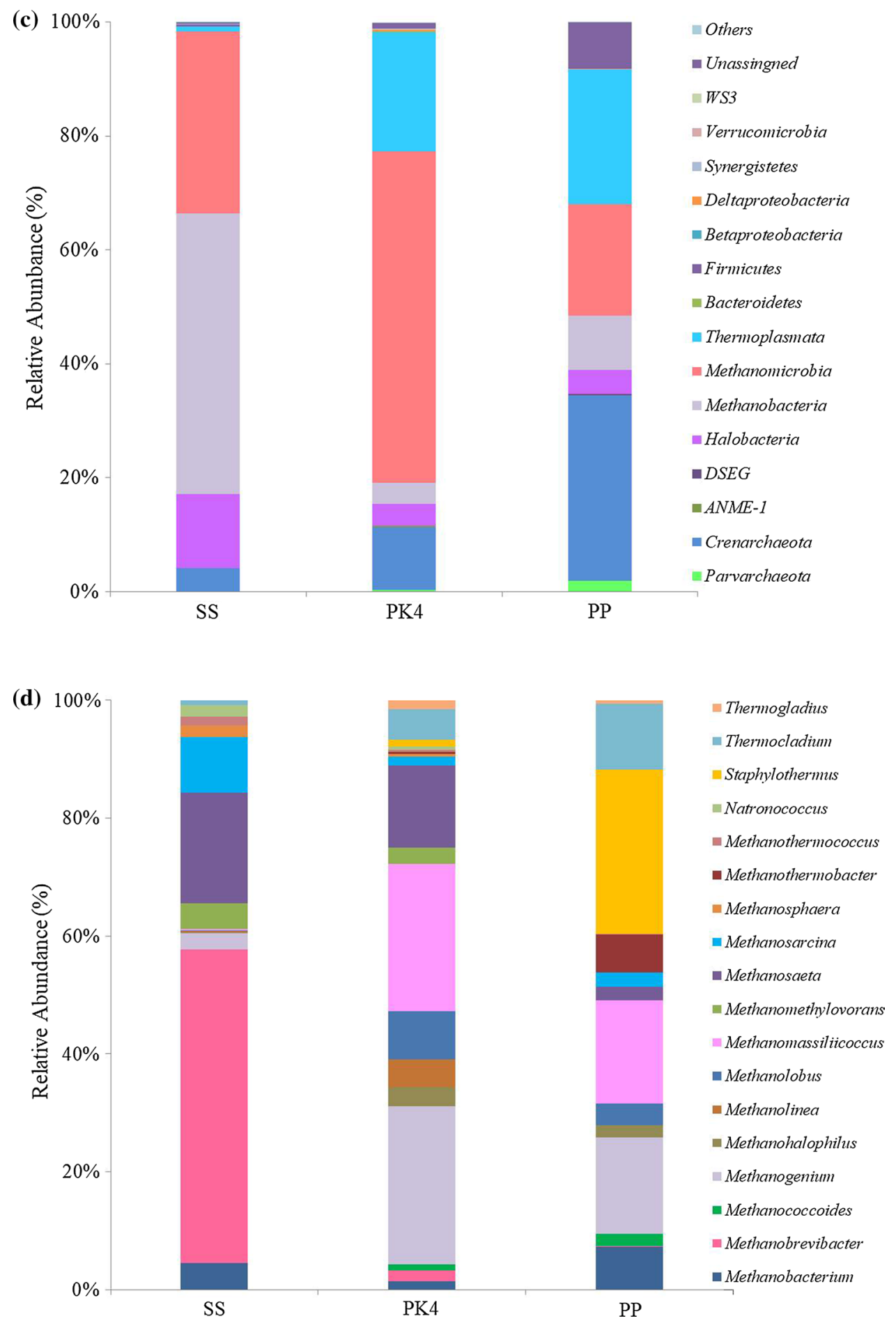
worth noting a percentage of 1\% in PK4 and PP sediments. The predominance of genus Methanosarcina throughout digestion strongly indicated that this archaea has important functions in methanogenesis of organic matter (Wintsche et al. 2016). Methanosaeta genus was present too with relatively high percentage in both SS (13.5\%) and PK4 (10\%). Methanosaeta genus was characterized by an exclusive use of acetate as a substrate for producing methane and was widely distributed in nature as methane producer (Mori et al. 2012). Hydrogenotrophic methanogens were represented by Methanobacterium genus, isolated from sludge deposited in a crude oil storage tank and mostly detected in PP sediment at $4 \%$ and in SS sediment at 3.2\% (Mori and Harayama 2011). Within Methanomicrobia class in PK4 sediment, Methanolinea genus was present at 3.3\% of abundance, and this genus is implicated in the final step of organic substances degradation and generally obtained from methanogenic digester of municipal sewage sludge functioning in mesophilic conditions (Imachi et al. 2008). Mesophilic methylotrophic methanogen called Methanolobus genus was highly present at $5.8 \%$, generally found in saline environments (Mochimaru et al. 2009). Moreover, thermophilic methanogens were also present mostly in PP sediment; Methanothermobacter genus conserved energy by reducing $\mathrm{CO}_{2}$ from $\mathrm{H}_{2}$ to produce $\mathrm{CH}_{4}$ and synthesized all of its cellular components from these same gaseous substrates as well as $\mathrm{N}_{2}$ or $\mathrm{NH}_{4}{ }^{+}$and inorganic salts (Smith et al. 1997). Methanomassiliicoccus genus was rare $(<1 \%)$ in SS sediment compared to an abundance of $18 \%$ in PK4 and 9.7\% in PP. The marine halophilic Methanogenium genus was noticed at $19.26 \%$ in PK4 sediment and at $9.03 \%$ in PP sediment. This genus was isolated from marine sediments and was able to grow by reducing $\mathrm{CO}_{2}$ with $\mathrm{H}_{2}$ or formate as electron donor (Chong et al. 2002). Furthermore, Natronococcus genus including aerobic halophilic archaea was classified within Halobacteria class and was present in SS sediment at $1.39 \%$ and in PK4 sediment at $0.37 \%$. This genus is generally found in alkaline, hypersaline lakes and soils (Kamekura 1998). However, within Crenarchaeota phylum, the dominance of the hyperthermophilic and heterotrophic Staphylothermus genus in PP sediment at $15.4 \%$ was noted. The extremely thermophilic Thermocladium genus, isolated from acidic areas with $6.2 \%$ in PP sediment and 3.7\% in PK4, utilized carbon sources for growth and required sulfur, thiosulfate as possible electron acceptors (Itoh et al. 1998). Likewise, the hyperthermophilic heterotrophic Thermogladius genus was recorded in PK4 sediment at 1.1\% PK4 and in PP sediment at $0.3 \%$. This genus is primarily found in terrestrial acid-sulfate areas and implicated in fermentation metabolism to produce organic acids from a variety of complex organic substrates (Osburn and Amend 2011).

The total microbial population quantitatively present in sediments expressed as 16S rRNA gene concentration Q-PCR analysis is reported in Table 1. Thus, PK4 sediment presented both the highest mean number of bacterial $16 \mathrm{~S}$ rRNA gene copies of 1130 copie gene/g dw $\left( \pm 630 \times 10^{7}\right)$ and archaeal $16 \mathrm{~S}$ rRNA gene copies with a mean number of 4.2 copie gene/g dw $\left( \pm 2 \times 10^{7}\right)$. Wastewater outfalls may influence the total and active bacterial community abundance and it seems that the highest bacterial and archaeal abundance was noticed in sediments affected by terrestrial inputs, receiving sewage discharges with a high toxic potential. The archaeal community represented 1.4, 0.4 and $4 \%$ of the total prokaryotic population (Bacteria and Archaea) for SS, PK4 and PP sediments, respectively. The methanogenic community abundance presented $1.42 \%$ of total archaeal communities in PK4 sediment. Thus, Q-PCR showed that the bacteria dominated the prokaryotic community at the studied areas. The highest archaea percentage of $4 \%$ is observed in PP site which is the most contaminated site with PAHs and TS content, certainly due to combined effects of terrigenous organic matter inputs and harbor activities pollution (Zhang et al. 2009).

\section{Correlation between biochemical characterization and microbial communities' diversity in sediments}

Marine coastal sediments are subject to various natural and anthropogenic inputs. Indeed, the community structure variability including bacteria and archaea could be explained statistically by a selection of biochemical variables (Misson et al. 2016). In this study, "Spearman correlation" was used in order to investigate the correlation between chemical parameters and microbial communities' structure. As observed in Table 5, the organic matter contribution to microbial diversity patterns appeared significant. Therefore, important links between TOC content and bacterial communities assigned within Clostridia class like Acetobacterium, Fusibacter, Clostridiisalibacter, Clostridium, Halanaerobium and Romboutsia, also Cellulophaga and Bifidobacterium genera were observed. These bacteria are implicated in hydrolysis, acidogenesis and degradation of complex organic compounds. In addition, Seohaeicola and Calothrix genera, with the ability to produce hydrogen sulfide, were related to the occurrence of the highest $\mathrm{SO}_{4}{ }^{2-}$ concentration in PK4 sediment. Furthermore, the correlation underscored between Thermocladium and Thermogladius genera and sulfate content explained that PP and PK4 sediments are located in 


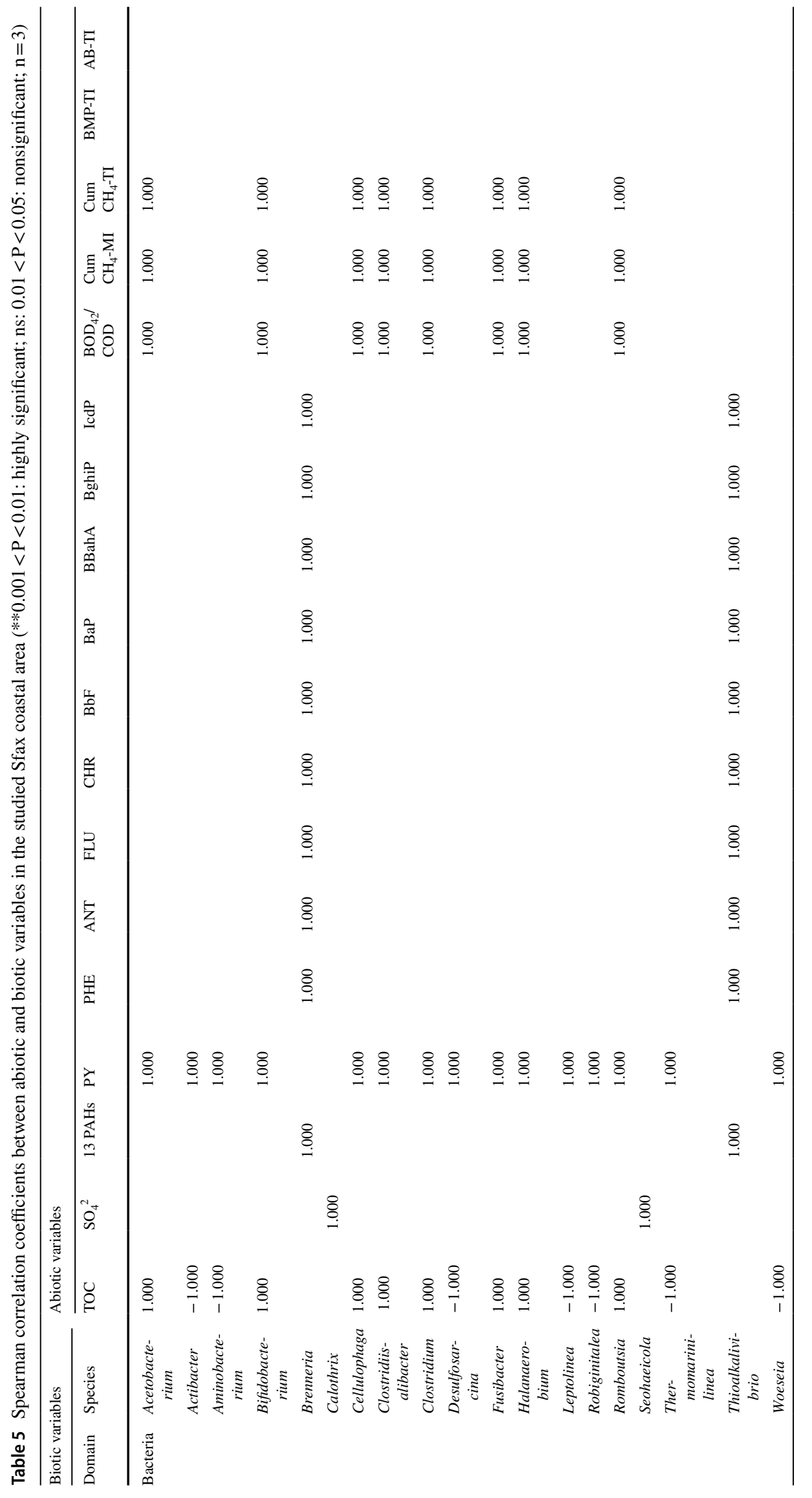




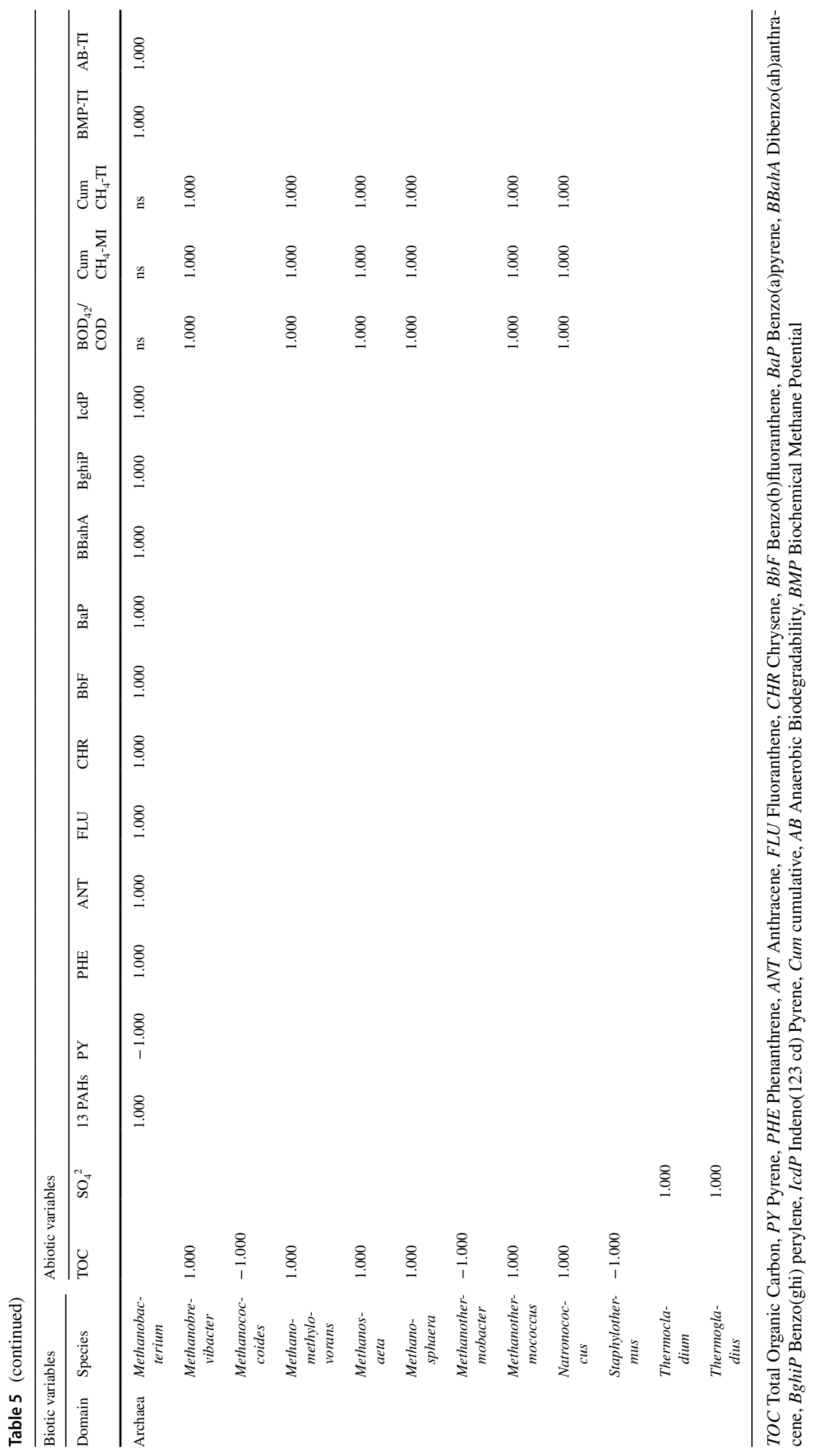


terrestrial acid-sulfate areas. The aerobic biodegradation potential showed that the best ultimate aerobic biodegradability $\left(\mathrm{BOD}_{42} / \mathrm{COD}_{\mathrm{T}}\right)$ observed in SS sediment correlated positively with the aerobic genus Cellulophaga and other genera including Romboutsia, Halanaerobium, Fusibacter, Clostridium, Clostridiisalibacter, Bifidobacterium and Acetobacterium. Moreover, a positive relationship was noticed between almost all the detected bacterial classes, except Cyanobacteria, Alphaproteobacteria and Betaproteobacteria, and the four-ring PAHs pyrene, which was mostly abundant in PP sediment. As shown in Table 5, the PAH contamination, including LMW-PAHs and HMW-PAHs and the highest PAH concentration $\left(981 \mu \mathrm{g} \mathrm{kg}^{-1} \mathrm{dw}\right)$, proved to be strongly related to Brenneria and Thioalkalivibrio genera which were mostly present in PP sediment. These PAHs were positively correlated with Methanobacterium genus. This can be explained by the abundance of Methanobacterium petrolearium species in SS sediment and Methanobacterium ferruginis species in PP sediment, which were in agreement with the presence of LMWPAHs, having both petrogenic and combustion sources, and HMW-PAHs, which were predominantly of pyrogenic origin. The relative high contribution of low and moderate molecular weight PAHs in PP sediment (60\% of total PAHs) may explain the occurrence of Methanobacterium genus, positively correlated with BMP-TI (highest value in PP sediment) and the anaerobic biodegradability-TI, and able to degrade bio-available molecules as shown in previous studies (Potter et al. 1999; Straube et al. 1999). Hence, decreases or very significant shifts in microbial diversity in response to PAHs contamination were reported (Correa et al. 2010; Guazzaroni et al. 2013). Therefore, organic contaminants correlated well with the highest cumulative $\mathrm{CH}_{4}$-MI recorded in SS sediment, with a rapid acclimation stage, and the cumulative $\mathrm{CH}_{4}-\mathrm{TI}$, which was in accordance with the abundance of Natronococcus, Methanothermococcus, Methanosphaera, Methanomethylovorans, Methanosaeta genera and also Methanobrevibacter genus, showing then the presence of industrial and municipal sources in SS site comparing to other studied sediments.

Overall, these findings suggest that anthropogenic inputs can deeply influence microbial communities' richness and diversity in surface coastal sediments. The anthropogenic activities across the coastal zone of the Gulf of Gabès, displaying sediments with heterogeneous contaminants, promote a high diversification of procaryotic and archaeal communities, likely supposing the hypothesis of well-adapted communities to various contaminants mixtures. These results open perspectives for understanding the potential contribution of communities to actions of contaminant bioremediation to elucidate the functioning of the sediment microbiome with the aim of evaluating the ecological and biochemical consequences of chemical pollution on coastal ecosystems.

\section{Conclusion}

The study indicated that superficial sediments from all sampling sites in the Sfax coastal area in the Gulf of Gabès received intensive anthropogenic inputs affecting the ecosystem health. Total concentrations of 13 PAHs in sediments reached $981 \mu \mathrm{g} \mathrm{kg}^{-1} \mathrm{dw}$. This revealed a relationship between the contamination levels and the anthropogenic pressures on the coastline. The physicochemical characterization of sediments showed contamination by organic and inorganic compounds. The high organic matter reactivity resulting in the almost complete organic matter consumption and the little methane production indicated that industrial effluents were enriched with non-biodegradable substances. This was confirmed by the COD/BOD ratios showing the presence of recalcitrant chemical pollution. Thus, the contamination degree in the studied ecosystems allowed the selection of efficient microorganisms involved in the PAH removing and organic biodegradation process under anaerobic conditions. Then, a bioremediation strategy could be efficient knowing microbial communities and contaminant characterization of SS sediment in order to metabolize organic and inorganic compounds with the objective of preservation of aquatic environment and the maintain of the sustainability of its resources.

Supplementary Information The online version contains supplementary material available at https://doi.org/10.1007/s13762-021-03307-0.

Acknowledgements This work received the financial support of the IRD French-Tunisian International Joint Laboratory (LMI) "COSYSMed" (Contaminants et Ecosystèmes Sud Méditerranéens), http://www. cosysmed.com/. Mariem Jeddi was supported by the Ministry of Higher Education and Scientific Research, Tunisia, in the frame of "Contract Programme" with Centre of Biotechnology of Sfax. We acknowledge Laboratory of Environmental Biotechnology (LBE, Univ Montpellier, INRA, Narbonne, France) for performing aerobic and anaerobic potential analyses, PAH analysis and also chemical analysis. We acknowledge Laboratory of Phytoplanctonology of the Faculté des Sciences de Bizerte, Université de Carthage, Bizerte, Tunisia, for statistical analyses. We thank as well Doriane Delanghe from the sedimentology laboratory of the Centre Européen de Recherche et d'Enseignement des Géosciences de l'Environnement (CEREGE, UMR 7330, Aix-en Provence, France) for particle size distribution analysis (granulometry). 


\section{Declarations}

Conflict of interest The authors declare that they have no conflict of interest.

\section{References}

Abell GCJ, Ross DJ, Keane J, Holmes BH, Robert S, Keough M, Eyre B, Volkman J (2014) Niche differentiation of ammonia-oxidising archaea (AOA) and bacteria (AOB) in response to paper and pulp mill effluent. Microbiol Ecol 67:758-768

Acosta-Gonzalez A, Marques S (2016) Bacterial diversity in oil-polluted marine coastal sediments. Curr Opin Biotechnol 38:24-32

Akhiar A, Torrijos M, Battimelli A, Carrere H (2016) Comprehensive characterization of the liquid fraction of digestates from full-scale anaerobic co-digestion. Waste Manag 59:118-128

Aloulou F, Elleuch B, Kallel M (2012) Benthic foraminiferal assemblages as pollution proxies in the northern coast of Gabes Gulf. Tunisia Env Monit Assess 184:777-795

Altschul SF, Madden TL, Schäffer AA, Zhang J, Zhang Z, Miller W, Lipman DJ (1997) Gapped BLAST and PSI-BLAST : a new generation of protein database search programs. Nucleic Acids Res 25:3389-3402

APHA (1985) Standard methods for the examination of water and wastewater, 16th edn. American Public Health Association, Washington

Aylagas E, Borja A, Tangherlini M, Dell'Anno A, Corinaldesi C, Michell CT, Irigoien X, Danovaro R, Rodríguez-Ezpeleta N (2017) A bacterial community-based index to assess the ecological status of estuarine and coastal environments. Mar Pollut Bull 114:679-688

Barhoumi B, Lemenach K, Devier M (2014) Polycyclic aromatic hydrocarbons (PAHs) in surface sediments from the Bizerte Lagoon, Tunisia : levels, sources, and toxicological significance. Environ Monit Assess 186:2653-2669
Battimelli A, Loisel D, Garcia-bernet D, Carrere H, Delgenes J (2010) Combined ozone pretreatment and biological processes for removal of colored and biorefractory compounds in wastewater from molasses fermentation industries. J Chem Technol Biotechnol 85:968-975

Baumard P, Budzinski H, Michon Q, Garrigues P, Burgeot T, Bellocq J (1998) Origin and Bioavailability of PAHs in the Mediterranean Sea from Mussel and sediment records. Estuar Coast Shelf Sci 47:77-90

Bel Hassen M, Drira Z, Hamza A, Ayadi H, Akrout F, Messaoudi S, Issaoui H, Aleya L, Bouaïn A (2009) Phytoplankton dynamics related to water mass properties in the Gulf of Gabes: ecological implications. J Mar Syst 75:216-226

Ben Ameur W, Trabelsi S, Driss MR (2010) Polycyclic aromatic hydrocarbons in superficial sediments from Ghar El Melh Lagoon. Tunisia Bull Env Contam Toxicol 85:184-189

Caporaso JG, Lauber CL, Walters WA, Berg-lyons D, Lozupone CA, Turnbaugh PJ, Fierer N, Knight R (2010) Global patterns of 16S rRNA diversity at a depth of millions of sequences per sample. Proc Natl Acad Sci U S A 108:4516-1522

Casamayor EO, Massana R, Benlloch S, Øvreås L, Díez B, Goddard VJ, Gasol JM, Joint I, Rodríguez-valera F, Pedrós-alió C (2002) Changes in archaeal, bacterial and eukaryal assemblages along a salinity gradient by comparison of genetic fingerprinting methods in a multipond solar saltern. Environ Microbiol 4:338-348

Chertkov O, Sikorski J, Brambilla E, Lapidus A, Copeland A, Detter JC, Bruce D, Tapia R, Goodwin L, Pitluck S (2010) Complete genome sequence of Aminobacterium colombiense type strain (ALA-1 T). Stand Genom Sci 2:280-289

Chong SC, Liu Y, Cummins M, Valentine DL, Boone DR (2002) Methanogenium marinum sp. nov., a $\mathrm{H} 2$-using methanogen from Skan Bay, Alaska, and kinetics of $\mathrm{H} 2$ utilization. Antonie van Leeuwenb 81:263-270

Correa PA, Lin L, Just CL, Hu D, Hornbuckle KC, Schnoor JL, Van Aken B (2010) The effects of individual PCB congeners on the soil bacterial community structure and the abundance of biphenyl dioxygenase genes. Environ Int 36:901-906

D'Ortenzio F, D'Alcalà MR (2009) On the trophic regimes of the Mediterranean Sea : a satellite analysis. Biogeosciences 6:139-148 
Dang DH, Tessier E, Lenoble V, Durrieu G, Omanovi D, Mullot J, Pfeifer H, Mounier S, Garnier C (2014) Key parameters controlling arsenic dynamics in coastal sediments : an analytical and modeling approach. Mar Chem 161:34-46

Dang DH, Lenoble V, Durrieu G, Omanovic D, Mullot J, Mounier S, Garnier C (2015) Seasonal variations of coastal sedimentary trace metals cycling : insight on the effect of manganese and iron (oxy) hydroxides, sulphide and organic matter. Mar Pollut Bull 92:113-124

De Luca G, Furesi A, Leardi R, Micera G, Panzanelli A, Costantina P, Sanna G (2004) Polycyclic aromatic hydrocarbons assessment in the sediments of the Porto Torres Harbor (Northern Sardinia, Italy). Mar Chem 86:15-32

Devereux R, Delaney M, Widdel F, Stahl DA (1989) Sulfate-reducing eubacteria. J Bacteriol 171:6689-6695

Dias MF, Colturato LF, de Oliveira JP, Leite RL, Oliveira G, Chernicharo CA, de Arauj JC (2016) Metagenomic analysis of a desulphurisation system used to treat biogas from vinasse methanisation. Bioresour Technol 205:58-66

Drira Z, Kmiha-megdiche S, Sahnoun H, Hammami A, Allouche N, Tedetti M, Ayadi H (2016) Assessment of anthropogenic inputs in the surface waters of the southern coastal area of Sfax during spring (Tunisia, Southern Mediterranean Sea). Mar Pollut Bull 104:355-363

Duran R, Ranchou-Peyruse M, Menuet V, Monperrus M, Bareille G, Goni M, Salvado J, Amouroux D, Guyoneaud R, Donard OF, Caumette P (2008) Mercury methylation by a microbial community from sediments of the Adour Estuary (Bay of Biscay, France) Urban district. Environ Pollut 156:951-958

Edgar RC (2010) Search and clustering orders of magnitude faster than BLAST. Bioinformatics 26:2460-2461

El Zrelli R, Courjault-Radé P, Rabaoui L, Daghbouj N, Mansour L, Balti R, Castet S, Attia F, Michel S, Bejaoui N (2017) Biomonitoring of coastal pollution in the Gulf of Gabes (SE, Tunisia): use of Posidonia oceanica seagrass as a bioindicator and its mat as an archive of coastal metallic contamination. Environ Sci Pollut Res 24:22214-22225

Fadhlaoui K, Hania W, Ben Postec A, Fauque G, Hamdi M, Ollivier B, Fardeau M (2015) Anaerobic bacterium isolated from a mesothermic Tunisian spring. Int J Syst Evol Microbiol 65:3501-3506

Fourati R, Tedetti M, Guigue C, Goutx M, Garcia N, Zaghden H, Sayadi S, Elleuch B (2018) Sources and spatial distribution of dissolved aliphatic and polycyclic aromatic hydrocarbons in surface coastal waters from the Gulf of Gabès (Tunisia, Southern Mediterranean Sea). Progr Oceanogr 163:232-247

Gauthier TD (2001) Detecting trends using spearman's rank correlation coefficient. Environ Forensics 2:359-362

Guazzaroni M-E, Herbst FA, Lores I, Tamames J, Pelaez AI, LopezCortés N, Alcaide M, Del Pozo MV, Vieites J, Von Bergen M, Gallego JL, Bargiela R, Lopez-Lopez A, Pieper D, Rossello-Mora R, Sanchez J, Seifert J, Ferrer M (2013) Metaproteogenomic insights beyond bacterial response to naphthalene exposure and bio-stimulation. ISME J 7:122-136

Guigue C, Tedetti M, Dang DH, Mullot J-U, Garnier C, Goutx M (2017) Remobilization of polycyclic aromatic hydrocarbons and organic matter in seawater during sediment resuspension experiments from a polluted coastal environment: insights from Toulon Bay (France). Environ Pollut 229:627-638

Hayes LA, Nevin KP, Lovley DR (1999) Role of prior exposure on anaerobic degradation of naphthalene and phenanthrene in marine harbor sediments. Org Geochem 30:937-945

Imachi H, Sakai S, Sekiguchi Y, Hanada S, Kamagata Y, Ohashi A, Harada H (2008) Methanolinea tarda gen. nov., sp. nov., a methaneproducing archaeon isolated from a methanogenic digester sludge. Int J Syst Evol Microbiol 58:294-301

Itoh T, Suzuki K, Nakase T (1998) Thermocladium modestius gen. nov., sp. nov., a new genus of rod-shaped, extremely thermophilic crenarchaeote. Int J Syst Bacteriol 48:879-887

Jabari L, Gannoun H, Khelifi E, Cayol J (2016) Bacterial ecology of abattoir wastewater treated by an anaerobic digestor. Braz J Microbiol 47:73-84

Jeddi M, Karray F, Loukil S, Mhiri N, Ben Abdallah M, Sayadi S (2020) Anaerobic biological treatment of industrial saline wastewater : fixed bed reactor performance and analysis of the microbial community structure and abundance. Environ Technol 41:1715-1725

Kahng H, Chung BS, Lee D, Jung JS, Park JH, Jeon CO (2009) Cellulophaga tyrosinoxydans sp. nov., a tyrosinase- producing bacterium isolated from seawater. Int J Syst Evol Microbiol 59:654-657

Kamekura M (1998) Diversity of extremely halophilic bacteria. Extremophiles 2:289-295

Karthikeyan R, Bhandari A (2001) Anaerobic biotransformation of aromatic and polycyclic aromatic hydrocarbons in soil microcosms: a review. J Hazard Subst Res 3:1-19

Kessabi K, Annabi A, Ibn A, Hassine H, Bazin I, Mnif W (2013) Chemosphere possible chemical causes of skeletal deformities in natural populations of Aphanius fasciatus collected from the Tunisian coast. Chemosphere 90:2683-2689

Kosson DS, Van Der Sloot HA, Sanchez F, Garrabrants AC (2002) An integrated framework for evaluating leaching in waste management and utilization of secondary materials. Environ Eng Sci 19:159-204

Li GC, Xia XH, Yang ZF, Wang R, Voulvoulis N (2006) Distribution and sources of polycyclic aromatic hydrocarbons in the middle and lower reaches of the Yellow River. China Environ Pollut 144:985-993

Louiz I, Kinani S, Gouze M, Ben-attia M, Menif D, Bouchonnet S (2008) Monitoring of dioxin-like, estrogenic and anti-androgenic activities in sediments of the Bizerta lagoon (Tunisia) by means of in vitro cell-based bioassays : Contribution of low concentrations of polynuclear aromatic hydrocarbons (PAHs). Sci Total Environ 402:318-329

MechichiStackebrandtGad'onFuchs TENG (2002) Phylogenetic and metabolic diversity of bacteria degrading aromatic compounds under denitrifying conditions, and description of Thauera phenylacetica sp. nov., Thauera aminoaromatica sp. nov., and Azoarcus buckelii sp. nov. Arch Microbiol 178:26-35

Miller TL, Lin C (2002) Description of Methanobrevibacter gottschalkii sp. nov., Methanobrevibacter thaueri sp. nov., Methanobrevibacter woesei sp. nov. and Methanobrevibacter wolinii sp. nov. Int J Syst Evol Microbiol 52:819-822

Misson B, Garnier C, Lauga B, Huy D, Ghiglione J, Mullot J, Duran R, Pringault O (2016) Science of the total environment chemical multi-contamination drives benthic prokaryotic diversity in the anthropized Toulon Bay. Sci Total Environ 556:319-329

Mochimaru H, Tamaki H, Hanada S, Imachi H, Nakamura K, Sakata S, Kamagata Y (2009) Methanolobus profundi sp. nov., a methylotrophic methanogen isolated from deep subsurface sediments in a natural gas field. Int J Syst Evol Microbiol 59:714-718

Mori K, Harayama S (2011) Methanobacterium petrolearium sp. nov. and Methanobacterium ferruginis sp. nov., mesophilic methanogens isolated from salty environments. Int J Syst Evol Microbiol 61:138-143

Mori K, Iino T, Suzuki K, Yamaguchi K, Kamagata Y (2012) Aceticlastic and $\mathrm{NaCl}$-requiring methanogen "Methanosaeta pelagica" sp. nov., isolated from marine tidal flat sediment. Appl Env Microbiol 78:3416-3423 
Muyzer G, Sorokin DY, Mavromatis K, Lapidus A, Clum A, Ivanova N, Pati A, D'Haeseleer P, Woyke T, Kyrpides NC (2011) Complete genome sequence of "Thioalkalivibrio sulfidophilus" HLEbGr7. Stand Genomic Sci 4:23-35

Mzoughi N, Chouba L (2011) aromatic hydrocarbons between water, suspended particulate matter, and sediment in harbours of the West coastal of the Gulf of Tunis (Tunisia). J Environ Monit 13:689-698

Nadkarni MA, Martin FE, Jacques NA, Hunter N (2002) Determination of bacterial load by real-time PCR using a broad-range (universal) probe and primers set. Microbiology 148:257-266

Ommedal H, Torsvik T (2007) Desulfotignum toluenicum sp. nov., a novel toluene-degrading, sulphate-reducing bacterium isolated from an oil-reservoir model column. Int J Syst Evol Microbiol 57:2865-2869

Osburn MR, Amend JP (2011) Thermogladius shockii gen. nov., sp.nov., a hyperthermophilic crenarchaeote from Yellowstone National Park, USA. Arch Microbiol 193:45-52

Padox J.M, Hennebert P, Benard A, Mancioppi L (2010) Qualité chimique des sédiments marins en France : Synthèse des bases de données disponibles

Potter CL, Glaser JA, Chang LW, Meier JR, Dosani MA, Herrmann RF (1999) Degradation of polynuclear aromatic hydrocarbons under bench-scale compost conditions. Environ Sci Technol 33:1717-1725

Rabaoui L, Balti R, El Zrelli R, Tlig-Zouari S (2014) Assessment of heavy metals pollution in the gulf of Gabes (Tunisia) using four mollusk species. Mediterr Mar Sci 15:45-58

Raposo F, De la Rubia MA, Fernandez-Cegri V, Borja R (2011) Anaerobic digestion of solid organic substrates in batch mode: an overview relating to methane yields and experimental procedures. Renew Sustain Energy Rev 16:861-877

Rhaouat O, El Kherrati I, El Khayyat F, Chiguer H, Ezziani K, Ibeda A, Fareh M, Saidi Y, El Kharim K, Belghyti D (2014) Physic-chemical evaluation of urban wastewater of the town of Sidi Kacem. Comput Water Energy Environ Eng 3:30-35

Sanchez-Mata A, Glémarec M, Mora J (1999) Physico-chemical structure of the benthic environment of a Galician ria (Ria de AresBetanzos, north-west Spain). J Mar Biol Assoc United Kingdom 79:1-21

Smith DR, Doucette-stamm LA, Deloughery C, Lee H, Dubois J, Aldredge T, Bashirzadeh R, Blakely D, Cook R, Gilbert K, Harrison D, Hoang L, Keagle P, Lumm W, Pothier B, Qiu D, Spadafora R, Vicaire R, Wang Y, Wierzbowski J, Gibson R, Jiwani N, Caruso A, Bush D, Safer H, Patwell D, Prabhakar S, Dougall SMC, Shimer G, Goyal A, Pietrokovski S, Church GM, Daniels CJ, Mao J, Rice P, Nolling J, Reeve JN (1997) Complete genome sequence of Methanobacterium thermoautotrophicum deltaH: functional analysis and comparative genomics. J Bacteriol 179:7135-7155

Steinberg LM, Regan JM (2008) Phylogenetic comparison of the methanogenic communities from an acidic, oligotrophic fen and an anaerobic digester treating municipal wastewater sludge. Appl Environ Microbiol 74:6663-6671

Straube WL, Jones-meehan J, Pritchard PH, Jones WR (1999) Benchscale optimization of bioaugmentation strategies for treatment of soils contaminated with high molecular weight polyaromatic hydrocarbons. Resour Recycl 27:27-37

Takahashi S, Tomita J, Nishioka K, Hisada T, Nishijima M (2014) Development of a Prokaryotic universal primer for simultaneous analysis of bacteria and archaea using next-generation sequencing. PLOS ONE 9:1-9
Tangherlini M, Corinaldesi C, Rastelli E, Musco L, Armiento G, Danovaro R, Dell'Anno A (2020) Chemical contamination can promote turnover diversity of benthic prokaryotic assemblages: the case study of the Bagnoli-Coroglio bay (Southern Tyrrhenian Sea). Mar Environ Res 160:105040

Trabelsi S, Driss MR (2005) Polycyclic aromatic hydrocarbons in superficial coastal sediments from Bizerte Lagoon. Tunisia Mar Pollut Bull 50:344-359

Trably E, Delgènes N, Patureau D (2004) International journal of environmental statistical tools for the optimization of a highly reproducible method for the analysis of polycyclic aromatic hydrocarbons in sludge samples. Int J Environ Anal Chem 84:37-41

Ujevic I, Odzak N, Baric A (2000) Trace metal accumulation in different grain size fractions of the sediments from a semi-enclosed bay heavily contaminated by urban and industrial wastewaters. Water Res 34:3055-3061

Vidali M (2001) Bioremediation: an overview. Pure Appl Chem 73:1163-1172

Wintsche B, Glaser K, Sträuber H, Centler F, Liebetrau J, Harms $\mathrm{H}$, Kleinsteuber S (2016) Trace elements induce predominance among methanogenic activity in anaerobic digestion. Front Microbiol 7:1-12

Yamada T, SekiguchiY IH, Kamagata Y, Ohashi A, Harada H (2005) Diversity, localization, and physiological properties of filamentous microbes belonging to chloroflexi subphylum I in mesophilic and thermophilic methanogenic sludge granules. Appl Environ Microbiol 71:7493-7503

Yigiterhan O, Murray JW, Tugrul S (2011) Trace metal composition of suspended particulate matter in the water column of the Black Sea. Mar Chem 126:207-228

Yonglong L, Jijing Y, Li Q, Ueqing Z, Xiatian L, Chao S (2016) Impacts of land-based human activities on coastal and offshore marine ecosystems. Acta Ecologica Sin 36:1183-1191

Yoon J, Kang S, Lee S, Jung Y, Lee J, Oh T (2012) Marivita hallyeonensis sp. nov., isolated from seawater, reclassification of Gaetbulicola byunsanensis as Marivita byunsanensis comb.nov. and emended description of the genus Marivita Hwang et al. 2009. Int J Syst Evol Microbiol 62:839-843

Yunker MB, Macdonald RW, Vingarzan R, Mitchell RH, Goyette D, Sylvestre S (2002) PAHs in the Fraser River basin: a critical appraisal of $\mathrm{PAH}$ ratios as indicators of $\mathrm{PAH}$ source and composition. Org Geochem 33:489-515

Zaghden H, Kallel M, Elleuch B, Oudot J, Saliot A (2007) Sources and distribution of aliphatic and polyaromatic hydrocarbons in sediments of Sfax, Tunisia. Mediterr Sea Mar Chem 105:70-89

Zaghden H, Kallel M, Elleuch B, Oudot J, Saliot A, Sayadi S (2014) Evaluation of hydrocarbon pollution in marine sediments of Sfax coastal areas from the Gabes Gulf of Tunisia. Mediterr Sea Environ Earth Sci 72:1073-1082

Zaghden H, Serbaji MM, Saliot A, Sayadi S (2016) The Tunisian Mediterranean coastline: potential threats from urban discharges Sfax-Tunisian Mediterranean coasts. Desalin Water Treat 57:1-13

Zaghden H, Tedetti M, Serbaji MM, Elleuch B, Saliot A (2017) Origin and distribution of hydrocarbons and organic matter in the surficial sediments of the Sfax-Kerkennah channel (Tunisia, SouthernMediterranean Sea). Mar Pollut Bull 117:414-428

Zhang R, Lau SCK, Ki J, Thiyagarajan V, Qian P (2009) Response of bacterioplankton community structures to hydrological conditions and anthropogenic pollution in contrasting subtropical environments. FEMS Microbiol Ecol 69:449-460

Zouch H, Cabrol L, Chifflet S, Tedetti M, Karray F, Zaghden H, Sayadi S, Quéméneur M (2018) Effect of acidic industrial effluent release on microbial diversity and trace metal dynamics during resuspension of coastal sediment. Front Microbiol 9:3103 
Zrafi I, Bakhrouf A, Rouabhia M, Saidane-mosbahi D (2013) Aliphatic and aromatic biomarkers for petroleum hydrocarbon monitoring in Khniss Tunisian-Coast, (Mediterranean Sea). Proc Environ Sci $18: 211-220$
Zrafi-nouira I, Safi NMD, Bahri R, Aissi A, Abdennebi H, Ben Saidane D (2010) Distribution and sources of polycyclic aromatic hydrocarbons around a petroleum refinery rejection area in JarzounaBizerte (Coastal Tunisia). Soil Sediment Contam 19:292-306 